Article

\title{
Obesogenic Features of Food-Related Content Aimed at Children on YouTube
}

\author{
Victoria Tur-Viñes *, Araceli Castelló-Martínez, and Cecilia Barrilero-Carpio \\ Department of Communication and Social Psychology, University of Alicante, Spain \\ * Corresponding author (victoria.tur@gcloud.ua.es)
}

Submitted: 11 July 2021 | Accepted: 16 August 2021 | Published: 24 February 2022

\begin{abstract}
Obesity, and particularly childhood obesity, is considered an epidemic by the WHO because of the health problems it causes and its impact on the lives and environment of those who suffer from it. In this article, the term "obesogenic features" refers to the set of supposedly aggravating risk factors that could intensify the proven effect on minors of exposure to food-related media content. The article explores the characteristics of food-related content in YouTube videos aimed at children, with the objective of identifying videos that pose a high risk due to the presence of obesogenic arguments, as well as videos with innovative media trends. It presents an exploratory study of 293 videos ( $22 \mathrm{hr} 41 \mathrm{~min}$ ) aimed at children and containing food and/or food brands, posted from May 2020 to April 2021 on 28 YouTube channels of food brands and child YouTubers with the largest numbers of subscribers. Child YouTubers often appear to explicitly promote calorie intake as a diet alternative and to disseminate content in which the presence of low-nutrition foods undermines childhood obesity prevention policies. The sensitivity of this target audience and the highly emotional nature of the formats in which messages with obesogenic features appear, such as "challenges," point to an urgent need to adopt ethical standards and legal measures to regulate such content.
\end{abstract}

\section{Keywords}

advertising; children; child YouTubers; food; obesogenic features; YouTube

\section{Issue}

This article is part of the issue "New Narratives for New Consumers: Influencers and the Millennial and Centennial Generations" edited by Luis M. Romero-Rodríguez (Rey Juan Carlos University), Santiago Tejedor (Universitat Autònoma de Barcelona), and Inmaculada Berlanga (International University of La Rioja).

(C) 2022 by the author(s); licensee Cogitatio (Lisbon, Portugal). This article is licensed under a Creative Commons Attribution 4.0 International License (CC BY).

\section{Introduction}

\subsection{Obesity and Obesogenic Factors}

Obesity, and specifically childhood obesity, is considered an epidemic because of the health problems it causes and its impact on the lives and environment of those who suffer from it (Ebbeling et al., 2002; Lobstein et al., 2004). On the global level, the number of obese children and youth aged 5 to 19 has increased tenfold in the last 40 years (WHO, 2016). Obesity reflects an imbalance between what is ingested and what is consumed and is detected in the form of excess accumulated body fat (Castro et al., 2012; Correia, 2013; Giugliano \& Melo,
2004; Miranda-Chaves et al., 2008; Tenorio \& Cobayashi, 2011). In Spain, this condition is on the rise despite an overall decrease in Europe as a whole (Eurostat, 2020). In the last 30 years, the prevalence of child obesity in the country has quadrupled, reaching 10.3\% in 2017 (Coduras-Martínez et al., 2019) for the population aged from 2 to 17.

As García-Cortés (2016) observes, obesity is a very complex phenomenon determined by the confluence of several internal and external factors (mass media, social influence, family habits, cultural traditions, etc.). Previous research (Mussini \& Temporelli, 2013; Ruvalcaba-Ledezma et al., 2018; among others) has identified some influencing factors: expanded supply of 
industrially processed foods; low prices of high-calorie foods containing high levels of salt, fat, and sugar; and high prices of fruit and vegetables (Drewnowski \& Darmon, 2005; Food and Agriculture Organization of the United Nations, 2008; French, 2003; Peña \& Bacallao, 2005; Temporelli \& Monterubbianessi, 2011); increased consumption of fast food and processed food outside of the home by a growing segment of the population (Powell et al., 2006); less free time for food preparation (Chou et al., 2004); and an increased quantity of advertising for convenient and accessible industrial food that facilitates daily intake with a minimum of preparation effort, encouraging sedentary lifestyles (Da-Silva-Pinto et al., 2010; Pergher et al., 2010; Philipson \& Posner, 2003; Reis, Vasconcelos, \& Barros, 2011; Reis, Vasconcelos, \& Oliveira, 2011; Vázquez et al., 2010). Environmental factors are the primary causes of the development of obesity (Procter et al., 2008).

Cairns et al. (2009) reviewed the most rigorous studies of the effects of food product advertising. Children recognize that watching food advertising makes them feel hungry, increases their desire, and affects purchase intentions (Marshall et al., 2007). An Iranian study found that $90 \%$ of students surveyed made food choices under the influence of advertising (Maryam et al., 2005). A study by Olivares et al. (2003) reported that $40 \%$ of children surveyed had consumed food products that they had seen advertised. Studies by Aktaş-Arnas (2006) and Utter et al. (2006) provide evidence of a correlation between television viewing time and general consumption of the most frequently advertised foods. Exposure to food advertising has an impact on or is associated with significant changes in food preferences among children (Borzekowski \& Robinson, 2001; Chernin, 2008; Halford et al., 2008b; Norton et al., 2000; Robinson et al., 2007).

It has also been shown that exposure to food advertising is associated with a more frequent selection of less healthy foods and that it leads to an overall increase in food intake (Halford et al., 2004, 2007, 2008a; Wiecha et al., 2006). Boynton-Jarrett et al. (2003) demonstrated that increased television viewing among children was associated with reduced consumption of fruit and vegetables. Buijzen et al. (2008) identified the influence of parents' income and communication style in the consumption of brand products advertised on television. A prospective observational study (Wiecha et al., 2006) found a positive association between watching television and food calorie intake. Coon et al. (2001) found a significant association between television viewing during mealtimes and a lower-quality diet.

According to a study by Borzekowski and Robinson (2001), exposure to food advertising significantly increased the probability that children would choose a food product advertised over a product that was not advertised. Robinson et al. (2007) discovered that children aged three to five preferred the flavor of food and beverages presented with the McDonald's brand logo to the flavor of exactly the same products without the brand. This reveals that brand presence contributes significant added value.

\subsection{Brand Advertising on YouTube and the Role of the YouTuber}

As reflected in the literature review, studies of food advertising and consumption have focused largely on television. Qutteina et al. (2019) point to the importance of researching the phenomenon in the digital environment. Since its very first video was posted on April 23, 2005 (Me at the Zoo: http://bit.ly/me-at-the-zoo-yt), YouTube has grown exponentially and is now the world's largest video viewing platform, offering a new way of creating and sharing audiovisual content: More than 1,9 billion users in 91 countries and with 80 different languages log into YouTube each month (YouTube, n.d.).

YouTube is also the most popular social media platform with advertisers for disseminating related content (Castelló-Martínez et al., 2016). Thanks to the big audiences that many of its videos attract, YouTube has become one of the most profitable sites to invest in advertising aimed at increasingly younger viewers, a target audience of great interest to food product brands. While the first studies of the platform highlighted its philanthropic and collaborative nature (Arthurs et al., 2018), De-Aguilera-Moyano et al. (2018) examine the professionalization of YouTube, showing how it has shifted from an approach that represented a participatory culture toward the creation and dissemination of audiovisual content with commercial objectives (Holland, 2016).

YouTubers express opinions in a very convincing and persuasive way, and food brands are discovering their potential as a means of promoting their products to children (Castelló-Martínez \& Tur-Viñes, 2020). The community of followers that develop around their videos is the key to their success, although it is crucial to maintain a balance between specialized content and elements with a commercial objective (Ramos-Serrano \& Herrero-Diz, 2016, p. 115). Tur-Viñes and González-Río define YouTubers as:

Influencers who promote products, services, or ideas, authorized by their expertise in the area, who create experiences among their frequently massive audiences characterized by humor, the ability to entertain, and the presence of brands seeking spaces vested with credibility to communicate more effectively and empathetically. (2019, p. 1293)

YouTubers are key figures in teen culture, as influencers whose viewers spend their leisure time following them and are thus introduced to the use of multimedia platforms and formats aimed specifically at them (Aran-Ramspott et al., 2018; Montes-Vozmediano et al., 2018). The professionalization of child YouTubers on this platform is also worth highlighting, as their channels are characterized by a high level of sophistication, featuring 
videos that have undergone elaborate post-production and that include products advertised in an extremely natural way (Aznar-Díaz et al., 2019; López-Villafranca \& Olmedo-Salar, 2019).

The term "obesogenic features" refers to the set of supposedly aggravating risk factors that could intensify the proven effect on minors of exposure to food-related media content. Based on the contextualization offered above, we have posited the following as our first research question (RQ1): Is food and/or food brand-related content aimed at child audiences on YouTube founded on obesogenic arguments, such as low price, speed, convenience, short cooking time, and/or calorie intake as a diet alternative? Does it in any way encourage sedentary behavior?

\subsection{The Food Sector and Food-Related Content on Social Media}

The current challenge that the sector faces is responding effectively to new trends: a more aware consumer committed to caring for the environment, animal welfare, and healthier eating (Instituto Nacional del Consumo, 2014). The second research question is thus related to whether food and/or food brand-related content aimed at children on YouTube reflects these new trends (RQ2): Does the content engage with innovative media trends, such as the promotion of the environment, animal welfare, traditional production, or healthy eating practices?

More than half (53\%) of all food products bought in Spanish supermarkets contain sugars on their list of ingredients and $64 \%$ of regularly consumed products are ultra-processed foods (minimal presence of natural ingredients and excessive saturated fats, salt, and sugars; "Hábitos de alimentación en España," 2019). Of all sectors in Spain, the food sector has the fifth biggest advertising presence on television (Barlovento Comunicación, 2020), with advertising accounting for $17 \%$ of total investments in 2018, amounting to 296,2 million euros (InfoAdex, 2019).

The food sector represents $20.4 \%$ of interactions occurring on social media (IAB Spain, 2019). The data reflect the increased presence of advertising by food brands on social media platforms, while advertising investment in television has been in decline (CodurasMartínez et al., 2019, p. 109). Our third research question (RQ3) relates to the type of products with the biggest presence in food and/or food brand-related content aimed at children on YouTube: Does content related to ultra-processed foods predominate over content involving healthy foods?

\section{Method}

The objective of this study is to identify obesogenic arguments in food and/or food brand-related content aimed at children on YouTube and the presence of innovative media trends. Innovative media trends are used in the article to refer to elements that promote healthy eating, environmental care, animal welfare, etc. An exploratory qualitative-quantitative study was conducted based on a content analysis of videos posted from May 2020 to April 2021 on the Spanish YouTube channels of food brands and child YouTubers with the most subscribers according to SocialBlade. The initial universe was made up of 1,031 videos: 733 videos from 15 child YouTuber channels and 298 videos from 13 food brand channels. The final sample, shown in Table 1, consists of 293 videos (22 hr $41 \mathrm{~min}$ ) that combine the presence of children with the appearance of foods and/or food brands: 222 child YouTuber videos and 71 food brand videos.

A matrix was designed in Excel where the rows were assigned to the videos and the columns to the 11 variables studied (1: Low price; 2: Speed; 3: Convenience; 4: Short cooking time; 5: Calorie intake as a diet alternative; 6: Encouraging sedentary behavior; 7: Environment; 8: Animal welfare; 9: Traditional production; 10: Healthy food practices; 11: Prevalence of ultra-processed versus healthy foods). Data on the interaction with the video were added to complete the study (Subscribers; Videos since creation; Videos May 2020-April 2021; Videos analyzed), as well as the date of creation of each channel. The content analysis sheet is available as a Supplementary File.

Table 2 shows the congruence between the research questions, the dimensions of the study, and their relationship to the variables analyzed.

\section{Results}

We found obesogenic features in 50 (17.1\%) out of the total sample of 293 videos. Of those 50,41 are videos by child YouTubers (82\%), and $18.5 \%$ of the videos in this subsample exhibit some kind of obesogenic feature. The most common obesogenic argument is calorie intake as a diet alternative, both in the subsample of brands (we found eight out of nine videos with this feature) and in the child YouTuber subsample (this feature appears in 38 out of 41 videos). Speed appears in two videos (one on the channel of the child YouTuber Lady Pecas and the other on the channel The Crazy Haacks); convenience is mentioned in one video on the Lady Pecas channel and low price is referred to on the Adam Foods brand channel.

Child YouTubers often appear to encourage calorie intake as a diet alternative, expressing it with statements like the following:

- The Crazy Haacks' Hugo is shopping online: "Only chocolate, only cookies...chocolate is very important and very healthy. I think 20 bars is good...we're going to add a heap of chocolate, cookies" and he quips: "My mother doesn't know how to shop" (http://bit.ly/youtubersmenoresvideo4).

- Adri's father in Juega con Adri asks: "Who wants hamburgers?" and everyone shouts: "Me!" They end 
Table 1. Sample of YouTube channels.

\begin{tabular}{|c|c|c|c|c|c|c|}
\hline Channel & $\begin{array}{l}\text { Creation } \\
\text { date (DD/ } \\
\text { MM/YYYY) }\end{array}$ & Link & Subscribers & $\begin{array}{l}\text { Videos } \\
\text { since } \\
\text { creation }\end{array}$ & $\begin{array}{c}\text { Videos } \\
\text { May } \\
2020- \\
\text { April } \\
2021\end{array}$ & $\begin{array}{l}\text { Videos } \\
\text { analyzed }\end{array}$ \\
\hline \multicolumn{7}{|l|}{ Child YouTuber } \\
\hline Las ratitas & $18 / 10 / 2015$ & http://bit.ly/lasratitas & $23,100,000$ & 204 & 34 & 12 \\
\hline MikelTube & $30 / 08 / 2015$ & http://bit.ly/mikeltube-yt & $7,180,000$ & 757 & 55 & 9 \\
\hline The Crazy Haacks & 09/03/2015 & http://bit.ly/the-crazy-haacks & $3,650,000$ & 729 & 62 & 38 \\
\hline Los juguetes de Arantxa & 02/01/2015 & http://bit.ly/juguetes-arantxa & $3,750,000$ & 952 & 82 & 28 \\
\hline Las aventuras de Dani y Evan & $22 / 01 / 2015$ & http://bit.ly/aventuras-dani-evan & $2,740,000$ & 550 & 83 & 19 \\
\hline La diversión de Martina & 05/01/2015 & http://bit.ly/ladiversiondemartina & $4,070,000$ & 368 & 53 & 13 \\
\hline Jugando con Aby & $13 / 12 / 2015$ & http://bit.ly/jugandoconaby & $2,940,000$ & 433 & 31 & 17 \\
\hline El mundo de Clodett & $27 / 12 / 2016$ & http://bit.ly/elmundodeclodett & $2,760,000$ & 343 & 63 & 10 \\
\hline TeamNico & $04 / 11 / 2013$ & http://bit.ly/los-mundos-de-nico & $3,450,000$ & 532 & 58 & 9 \\
\hline Juega con Adri & $26 / 03 / 2018$ & http://bit.ly/juegaconadri & $3,970,000$ & 153 & 40 & 18 \\
\hline Divertiguay & $11 / 10 / 2016$ & http://bit.ly/divertiguay-yt & $2,540,000$ & 643 & 61 & 16 \\
\hline Leotube & $15 / 01 / 2018$ & http://bit.ly/leotube-yt & $2,340,000$ & 143 & 48 & 12 \\
\hline Ladypecas & $01 / 09 / 2015$ & http://bit.ly/ladypecas & $1,930,000$ & 512 & 52 & 19 \\
\hline Pino y Ares & $16 / 04 / 2018$ & http://bit.ly/pinoyares & $1,140,000$ & 87 & 5 & 1 \\
\hline Juguetes MaryVer & 09/06/2010 & http://bit.ly/maryver & 271,000 & 534 & 6 & 1 \\
\hline \multicolumn{7}{|l|}{ Food brand } \\
\hline Nestlé Spain & $15 / 02 / 2010$ & http://bit.ly/nestlesp & 43,500 & 383 & 100 & 14 \\
\hline Casa Tarradellas & $21 / 06 / 2011$ & http://bit.ly/casatarradellas & 46,300 & 215 & 35 & 3 \\
\hline Grefusa & $31 / 08 / 2012$ & http://bit.ly/grefusayt & 21,700 & 83 & 12 & 4 \\
\hline Nocilla & $09 / 02 / 2012$ & http://bit.ly/nocillayt & 25,900 & 49 & 9 & 6 \\
\hline Dino Aventuras Danonino & $19 / 04 / 2016$ & http://bit.ly/danoninoyt & 11,700 & 13 & 7 & 7 \\
\hline The Phoskiters by Phoskitos & 09/03/2018 & http://bit.ly/phoskitosyt & 5,100 & 112 & 7 & 7 \\
\hline Nesquik Spain & $07 / 08 / 2008$ & http://bit.ly/nesquiksp & 5,010 & 32 & 15 & 9 \\
\hline Kellogg's Spain & $27 / 01 / 2016$ & http://bit.ly/kelloggs-sp & 1,680 & 13 & 5 & 1 \\
\hline ColaCao & $25 / 06 / 2007$ & http://bit.ly/colacaoyt & 25,300 & 217 & 12 & 9 \\
\hline Hero Spain & $11 / 03 / 2013$ & http://bit.ly/hero-sp-yt & 1,390 & 90 & 10 & 0 \\
\hline Adams Foods & $10 / 07 / 2015$ & http://bit.ly/adamfoods & 5,670 & 60 & 29 & 11 \\
\hline Dulcesol & $07 / 10 / 2015$ & http://bit.ly/dulcesol & 2,230 & 144 & 46 & 0 \\
\hline \multirow[t]{2}{*}{ Galletas Gullón } & $30 / 05 / 2017$ & http://bit.ly/galletasgullon & 894 & 42 & 11 & 0 \\
\hline & & & & Total & 1,031 & 293 \\
\hline
\end{tabular}

up eating at a Burger King (http://bit.ly/youtubers menoresvideo5).

- Nico's parents (in Los Mundos de Nico) buy a meal at McDonald's and Nico remarks: "Kids, this challenge is going to be really easy because I'm tired and what could be better than eating heaps, and top of that, that it's McDonald's," while his mother says: "He [referring to Nico] isn't going to like this challenge; he's going to love it," and she adds: "I haven't eaten all day!" (http://bit.ly/youtubersmenoresvideo6).

In the entire sample, a total of 45 videos with innovative trends in food-related content were identified (15.4\%). Of these 45, 28 are videos by child YouTubers $(12.6 \%$ of this subsample), while $23.9 \%$ of the subsample of food brand videos promote innovative trends $(N=17)$.
The most popular innovative trend is the promotion of healthy eating practices.

In the food brand subsample, animal welfare appears in six videos, the environment in three, traditional production in one, and healthy eating practices in seven. One video by the brand Nesquick includes the caption: "Eat breakfast every day" (http://bit.ly/nesquickpracticassaludables). In the case of the subsample of child YouTuber videos, two promote the environment, 12 advocate traditional production, and 14 encourage healthy eating practices. This last trend is reflected in statements or situations such as:

- Las Ratitas: "I got the lettuce. I love lettuce. Remember that you should eat a lot of fruit and a lot of vegetables" (http://bit.ly/youtubersmenores video7). 
Table 2. Congruence between research questions, dimensions, and study variables.

\begin{tabular}{|c|c|c|}
\hline Research questions & Dimensions & Study variables \\
\hline $\begin{array}{l}\text { RQ1: Is food and/or food brand-related content } \\
\text { aimed at child audiences on YouTube founded on } \\
\text { obesogenic arguments? Does it in any way } \\
\text { encourage sedentary behavior? }\end{array}$ & Obesogenic features & $\begin{array}{l}\text { 1. Low price } \\
\text { 2. Speed } \\
\text { 3. Convenience } \\
\text { 4. Short cooking time } \\
\text { 5. Calorie intake as a diet alternative } \\
\text { 6. Encouraging sedentary behavior }\end{array}$ \\
\hline $\begin{array}{l}\text { RQ2: Does the content engage with innovative } \\
\text { media trends? }\end{array}$ & Innovative media trends & $\begin{array}{l}\text { 7. Environment } \\
\text { 8. Animal welfare } \\
\text { 9. Traditional production } \\
\text { 10. Healthy eating practices }\end{array}$ \\
\hline $\begin{array}{l}\text { RQ3: Does content related to ultra-processed } \\
\text { foods predominate over content involving } \\
\text { healthy foods? }\end{array}$ & Food and food brands & $\begin{array}{l}\text { 11. Prevalence of ultra-processed vs. } \\
\text { healthy foods }\end{array}$ \\
\hline
\end{tabular}

- Los juguetes de Arantxa: Arantxa is preparing a snack for her friends and one friend says to her: "Come on, you're even going to make orange juice?" Arantxa replies: "Yes, because it's very healthy" (http://bit.ly/youtubersmenoresvideo8).

Ultra-processed foods and healthy foods appear together in 65 videos (22.2\%). Healthy foods appear on their own in 57 videos (19.5\%), and ultra-processed foods in 171 videos $(58.4 \%)$. This means that ultra-processed food products are present in $80.5 \%$ of the total sample, while healthy foods appear in $41.6 \%$ of the videos.

In the food brand subsample, we identified 67 videos with ultra-processed foods (94.4\%) and four with healthy foods (5.6\%). In this subsample, the two types of food never appear together in any video. Two of the 13 food brand channels (17 out of 71 videos, or $23 \%$ ) with the most subscribers belong to healthy food brands (Nestle and Casa Tarradellas). However, the three ultraprocessed food brand channels (Nocilla, ColaCao, and Grefusa) are responsible for 19 (26.76\%) of the 71 videos and they are also among the channels with the most subscribers in this subsample.

The percentage of videos featuring ultra-processed food products is higher in the specific case of the child YouTuber subsample, amounting to $76.1 \%$ (104 videos with ultra-processed foods alone and 65 videos with both ultra-processed and healthy foods). Healthy foods appear on their own in 53 child YouTuber videos, which means they appear in a total of 118 videos in this subsample (53.2\%). In addition, we identified communicative elements that indicate a preference for ultra-processed food products over healthy foods. For example, when Martina D'Antiochia doesn't like the meal prepared for her, her father offers to make her something else: "Right this minute I'll make you some fried eggs or lasagna or schnitzel, so you won't go hungry." Martina smiles and thanks him, but her mother scolds her, saying: "It's spinach with fish for dinner," to which Martina makes a retching gesture.

Focusing on the presence of food products in videos by child YouTubers, 128 videos feature foods without a recognizable brand. The most common food types are cakes, pastries, and pies (103 appearances), confections and candies (48 appearances), fruit, vegetables, and legumes (36 appearances), prepared dishes like pizzas, hamburgers, or nuggets (34 appearances), dairy products (25 appearances), and French fries (20 appearances).

Table 3 presents a summary of the study results. Although obesogenic features make more appearances in the sample as a whole than innovative media trends in food and/or food brand-related content aimed at children (17.1\% compared to $15.4 \%)$, the two subsamples analyzed exhibit inverse patterns for these two dimensions. Videos by child YouTubers contain more

Table 3. Study results.

\begin{tabular}{|c|c|c|c|c|c|c|}
\hline \multirow{2}{*}{$\frac{\text { Dimension }}{\text { Obesogenic features }}$} & \multicolumn{2}{|c|}{$\begin{array}{l}\text { Subsample: Child } \\
\text { YouTuber channels } \\
\text { (222 videos) }\end{array}$} & \multicolumn{2}{|c|}{$\begin{array}{c}\text { Subsample: Food } \\
\text { brand channels } \\
\text { (71 videos) }\end{array}$} & \multicolumn{2}{|c|}{$\begin{array}{l}\text { Total sample } \\
\text { (293 videos) }\end{array}$} \\
\hline & 41 & $18.5 \%$ & 9 & $12.7 \%$ & 50 & $17.1 \%$ \\
\hline Innovative media trends & 28 & $12.6 \%$ & 17 & $23.9 \%$ & 45 & $15.4 \%$ \\
\hline Ultra-processed food products & 157 & $76.1 \%$ & 67 & $94.4 \%$ & 224 & $80.5 \%$ \\
\hline Healthy foods & 118 & $53.2 \%$ & 4 & $5.6 \%$ & 122 & $41.6 \%$ \\
\hline
\end{tabular}


arguments encouraging obesity ( $18.5 \%$ compared to $12.6 \%$ containing innovative media trends). Conversely, in food brand videos innovative media trends associated with consumer concerns are more prominent than obesogenic features (23.9\% compared to $12.7 \%$ ).

However, in both the total sample of videos analyzed and, in each subsample, ultra-processed food products make more appearances than healthy foods. In the case of food brands this constitutes a contradiction, as their videos include more arguments related to healthy eating practices but the food type, they display the most is ultra-processed.

\section{Discussion and Conclusions}

Based on the findings of this study, it is clear that content related to food products with low nutritional value on digital media platforms like YouTube is undermining obesity prevention policies aimed at children by encouraging them to ingest unhealthy food products by associating them with fun and enjoyment, consistent with the conclusions of Jiménez-Morales et al. (2019).

Although food brands advertising is less controversial than the content featured on child YouTuber channels, the communication of negative obesogenic features (low price, speed, convenience, short cooking time, calorie intake as a diet alternative, or sedentary behavior) offsets the presence of positive trends (promotion of environmentalism, animal welfare, traditional production, or healthy eating habits). The excessive presence of ultra-processed products is striking considering that they should not be present in a healthy diet for growing children.

The child YouTuber subsample is notable for videos featuring "challenges," tasks tackled by the YouTubers, who recount their experience to their followers in a narrative-based entertainment format. These challenges often involve the presence of foods and/or food brands and the inclusion of messages with a commercial objective, with obesogenic arguments like those identified in this study.

Brands want to show their commitment to effective health promotion by including advice like "walk for 30 minutes a day," "eat breakfast every day," "use the stairs," or "exercise and maintain a healthy diet" in their advertising. However, there are surprisingly few proactive messages of this kind on channels targeting children, which effectively squanders the greater influence and credibility that these channels enjoy with youngsters.

There is an urgent need to introduce ethical standards and legal measures to regulate this type of content in digital media. Further research is needed into digital content on social media starring, created by and/or targeting children.

Lines of future research could include international comparative studies designed to identify the weaknesses of self-regulatory systems. Perception studies of minor creators could also be helpful for identifying narrative construction strategies, exploring how YouTubers have evolved from creating narratives with toys to introducing products from the food sector into their storylines, the spontaneous or directed nature of their self-editing of content, or the level of their awareness of the effects of their influence on the community. There is also a need for the proposal of actions to raise the awareness of marketing/communication decision-makers in companies that produce high-calorie products. Moreover, extending the analysis of food brands to other sectors, such as technology, toys, or fashion, could provide data on cross-sectoral prevalence. Parental mediation and the potential influence (positive, negative, or neutral) of parents on their children's content constitutes another interesting line of research.

On the other hand, the responsibility of parents, as their children's legal guardians, for YouTube practices is a controversial issue. Some families have found their children's YouTube channels to be a convenient source of income. The monetization of the channel raises the question of the potential exploitation of school-age children. Do parents understand the limits of what is acceptable? What kind of life lessons are they giving their children in an environment where anything goes for the sake of entertainment? What consequences might overexposure have on the child's future? Are parents aware of the consequences that promoting the consumption of unhealthy products can have on other children?

The results of this study, which constitute an original contribution to the literature given the lack of previous research on the media strategies of food brands aimed at children on YouTube, reveal some disturbing combinations of advertising, social media, and obesity-promoting content. If we want children to grow up healthy, we must ensure that the videos they consume provide them with proper guidance on good nutrition. The media, food brands, politicians, and audiences must all take their share of the responsibility for this as soon as possible.

\section{Acknowledgments}

We thank Martin Boyd for English translation and the University of Alicante for the economic grant with reference number VIGROB-021FI.

\section{Conflict of Interests}

The authors declare no conflict of interests.

\section{Supplementary Material}

Supplementary material for this article is available online in the format provided by the author (unedited).

\section{References}

Aktaş-Arnas, Y. (2006). The effects of television food advertisement on children's food purchasing 
requests. Pediatrics International, 48(2), 138-145. http://dx.doi.org/10.1111/j.1442-200X.2006. 02180.x

Aran-Ramspott, S., Fedele, M., \& Tarragó, A. (2018). Funciones sociales de los YouTubers y su influencia en la preadolescencia [Social functions of YouTubers and their influence on pre-adolescence]. Comunicar, 57, 71-80. https://doi.org/10.3916/C57-2018-07

Arthurs, J., Drakopoulou, S., \& Gandini, A. (2018). Researching YouTube. Convergence, 24(1), 3-15. https://doi.org/10.1177/1354856517737222

Aznar-Díaz, I., Trujillo-Torres, J. M., Romero-Rodríguez, J. M., \& Campos-Soto, M. N. (2019). Generación niños YouTubers: Análisis de los canales YouTube de los nuevos fenómenos infantiles [Generation kids YouTubers: Analysis of the YouTube channels of the new children's phenomena]. Píxel-BIT Revista de Medios y Educación, 56, 113-128. https://doi.org/10.12795/ pixelbit.2019.i56.06

Barlovento Comunicación. (2020). Análisis mensual del comportamiento de la audiencia TV 2019 [Monthly analysis of TV audience behaviour 2019]. https://bit. ly/barlovento-2019

Borzekowski, D. L. G., \& Robinson, T. N. (2001). The 30second effect: An experiment revealing the impact of television commercials on food preferences of preschoolers. Journal of the American Dietetic Association, 101(1), 42-46. https://doi.org/10.1016/ S0002-8223(01)00012-8

Boynton-Jarrett, R., Thomas, T. N., Peterson, K. E., Wiecha, J., Sobol, A. M., \& Gortmaker, S. L. (2003). Impact of television viewing patterns on fruit and vegetable consumption among adolescents. Pediatrics, 112(6), 1321-1326. https://doi.org/10.1542/ peds.112.6.1321

Buijzen, M., Schuurman, J., \& Bomhof, E. (2008). Associations between children's television advertising exposure and their food consumption patterns: A household diary-survey study. Appetite, 50(2/3), 231-239. https://doi.org/10.1016/j.appet.2007.07.006

Cairns, G., Angus, K., \& Hastings, G. (2009). The extent, nature and effects of food promotion to children: A review of the evidence to December 2008. World Health Organization. https://bit.ly/cairns-etal-2009

Castelló-Martínez, A., Del-Pino-Romero, C., \& Tur-Viñes, V. (2016). Estrategias de contenido con famosos en marcas dirigidas a público adolescente [Celebrity content strategies for brands targeting teenage audiences]. Icono14, 14(1), 123-154. https://doi.org/ 10.7195/ri14.v14i1.883

Castelló-Martínez, A., \& Tur-Viñes, V. (2020). Obesidad y contenidos relacionados con la alimentación dirigidos a niños en YouTube [Obesity and food-related content for children on YouTube]. Clinical Obesity, 10(5), Article e12389. https://doi.org/10.1111/cob. 12389

Castro, A. M., Toledo-Rojas, A. A., Macedo-De-La-Concha, L. E., \& Inclán-Rubio, V. (2012). La obesidad infan- til, un problema de salud multisistémico [Childhood obesity, a multi-systemic health problem]. Revista Médica del Hospital General de México, 75(1), 41-49. https://bit.ly/castro-etal-2012

Chernin, A. (2008). The effects of food marketing on children's preferences: Testing the moderating roles of age and gender. Annals of the American Academy of Political and Social Science, 615(1), 101-118. https:// doi.org/10.1177/0002716207308952

Chou, S. Y., Grossmann, M., \& Saffer, H. (2004). An economic analysis of adult obesity: Results from the behavioral risk factor surveillance system. Journal of Health Economics, 23(3), 565-587. https://doi.org/ 10.1016/j.jhealeco.2003.10.003

Coduras-Martínez, A., Del-Llano-Senarís, J., \& GolMonserrat, J. (2019). La obesidad en España y sus consecuencias [Obesity in Spain and its consequences]. Fundación Gaspar Casal.

Coon, K. A., Goldberg, J., Rogers, B. L., \& Tucker, K. L. (2001). Relationships between use of television during meals and children's food consumption patterns. Pediatrics, 107(1), Article E7. https://doi.org/ 10.1542/peds.107.1.e7

Correia, R. P. (2013). A importância dos aspectos interdisciplinares da obesidade [The importance of the interdisciplinary aspects of obesity]. Revista de Ciências Médicas e Biológicas, 11(3), 269-270. https:// doi.org/10.9771/cmbio.v11i3.6842

Da-Silva-Pinto, I. C., De-Arruda, I. K. G., Da-Silva-Diniz, A., \& De-Souza-Cavalcanti, A. M. T. (2010). Prevalência de excesso de peso e obesidade abdominal, segundo parâmetros antropométricos, e associação com maturação sexual em adolescentes escolares [Prevalence of overweight and abdominal obesity, according to anthropometric parameters, and association with sexual maturation in school adolescents] Cadernos de Saúde Pública, 26(9), 1727-1737. https://doi.org/ 10.1590/S0102-311X2010000900006

De-Aguilera-Moyano, M., Castro-Higueras, A., \& PérezRufí, J. I. (2018). Entre broadcast yourself y broadcast whatever: La página de inicio de YouTube como síntesis de su estrategia empresarial [Between broadcast yourself and broadcast whatever: YouTube's homepage as a synthesis of its business strategy]. El Profesional de la Información, 28(2), Article e280206. https://doi.org/10.3145/epi.2019.mar.06

Drewnowski, A., \& Darmon, N. (2005). Food choices and diet costs: An economic analysis. Journal of Nutrition, 135(4), 900-904. https://doi.org/10.1093/jn/135.4. 900

Ebbeling, C. B., Pawlak, D. B., \& Ludwig, D. S. (2002). Childhood obesity: Public-health crisis, common sense cure. The Lancet, 360(9331), 473-482. https:// doi.org/10.1016/S0140-6736(02)09678-2

Eurostat. (2020). Overweight and obesity-BMI statistics. https://ec.europa.eu/eurostat/statistics-explained/ index.php?title=Overweight_and_obesity__BMI_statistics 
Food and Agriculture Organization of the United Nations. (2008). Aumento de los precios de los alimentos: Hechos, perspectivas, impacto y acciones requeridas. [Rising food prices: Facts, perspectives, impact and actions required]. In Conferencia de alto nivel sobre la seguridad alimentaria mundial: Los desafíos del cambio climático y la bioenergía (pp. 1-55). FAO. https:// bit.ly/fao-roma-2008

French, S. A. (2003). Pricing effects on food choices. Journal of Nutrition, 133(3), 841-843. https://doi.org/ 10.1093/jn/133.3.841S

García-Cortés, B. (2016). La obesidad infantil: Estado de la cuestión y posibles líneas de investigación futura [Childhood obesity: State of play and possible lines of future research]. Revista sobre la Infancia y la Adolescencia, 10, 77-97. https://doi.org/10.4995/reinad. 2015.3718

Giugliano, R., \& Melo, A. L. P. (2004). Diagnóstico de sobrepeso e obesidade em escolares: Utilização do índice de massa corporal segundo padrão internacional [Diagnosis of overweight and obesity in schoolchildren: Use of the body mass index according to international standards]. Jornal de Pediatria, 80, 129-134. https://doi.org/10.1590/S002175572004000200010

Hábitos de alimentación en España [Eating habits in Spain]. (2019, June 17). La Razón. https://bit.ly/ larazon-2019

Halford, J. C. G., Boyland, E. J., Cooper, G. D., Dovey, T. M., Smith, C. J., Williams, N., Lawton, C. L., \& Blundell, J. E. (2008a). Children's food preferences: Effects of weight status, food type, branding and television food advertisements (commercials). International Journal of Pediatric Obesity, 3(1), 31-38. https://doi.org/10.1080/17477160701645152

Halford, J. C. G., Boyland, E. J., Hughes, G., Oliveira, L. P., \& Dovey, T. M. (2007). Beyond-brand effect of television (TV) food advertisements/commercials on caloric intake and food choice of 5-7-year-old children. Appetite, 49(1), 263-267. https://doi.org/ 10.1016/j.appet.2006.12.003

Halford, J. C. G., Boyland, E. J., Hughes, G. M., Stacey, L., McKean, S., \& Dovey, T. M. (2008b). Beyondbrand effect of television food advertisements on food choice in children: The effects of weight status. Public Health Nutrition, 11(9), 897-904. https:// doi.org/10.1017/S1368980007001231

Halford, J. C. G., Gillespie, J., Brown, V., Pontin, E. E., \& Dovey, T. M. (2004). Effect of television advertisements for foods on food consumption in children. Appetite, 42(2), 221-225. https://doi.org/10.1016/ j.appet.2003.11.006

Holland, M. (2016). How YouTube developed into a successful platform for user-generated content. Elon Journal of Undergraduate Research in Communications, 7(1), 52-59. http://bit.ly/holland-2016

IAB Spain. (2019). Observatorio sectorial de redes sociales [Sectoral observatory of social networks]. https://bit.ly/iabspain-2019

InfoAdex. (2019). Estudio InfoAdex de la inversión publicitaria en España 2019 [InfoAdex study of advertising investment in Spain 2019]. http://bit.ly/infoadex2019

Instituto Nacional del Consumo. (2014). Las tendencias del consumo y del consumidor en el siglo XXI [Consumer and consumer trends in the 21st century]. https://bit.ly/min-inc-2014

Jiménez-Morales, M., Montaña, M., \& Vàzquez, M. (2019). Estrategias discursivas en la publicidad audiovisual de productos de bajo valor nutricional dirigidos al público infantil: Felices, valientes y obesos [Discursive strategies in the audiovisual advertising of products of low nutritional value aimed at children: Happy, brave and obese]. Palabra Clave, 22(3), 1-30. http://doi.org/10.5294/pacla.2019.22.3.10

Lobstein, T., Baur, L., \& Uauy, R. (2004). Obesity in children and young people: A crisis in public health. Obesity Reviews, 5, 4-85. https://doi.org/10.1111/ j.1467-789X.2004.00133.x

López-Villafranca, P., \& Olmedo-Salar, S. (2019). Menores en YouTube, ¿̇ocio o negocio? Análisis de casos en España y EUA [Minors on YouTube, entertainment or business? Analysis of cases in Spain and the USA]. El Profesional de la Información, 28(5), Article e280520. https://doi.org/10.3145/epi.2019. sep. 20

Marshall, D., O'Donohoe, S., \& Kline, S. (2007). Families, food, and pester power: Beyond the blame game? Journal of Consumer Behaviour, 6(4), 164-181. https://doi.org/10.1002/cb.217

Maryam, A., Mehdi, M. R., Masood, K., Mosoomeh, G., Nasrin, O., \& Yadollah, M. (2005). Food advertising on Iranian children's television: A content analysis and an experimental study with junior high school students keywords. Ecology of Food and Nutrition, 44(2), 123-133. https://doi.org/10.1080/ 03670240590923532

Miranda-Chaves, M. D. G. A., Marques, M. H., Dalpra, J. O., Rodrigues, P. A., Carvalho, M. F. D., \& Carvalho, R. F. D. (2008). Estudo da relação entre a alimentação escolar ea obesidade [Study of the relationship between school meals and obesity]. HU Revista, 34(3), 191-197. https://bit.ly/miranda-etal-2008

Montes-Vozmediano, M., García-Jiménez, A., \& MenorSendra, J. (2018). Los vídeos de los adolescentes en YouTube: Características y vulnerabilidades digitales [Teen videos on YouTube: Features and digital vulnerabilities]. Comunicar, 26(54), 61-69. https://doi.org/ 10.3916/C54-2018-06

Mussini, M., \& Temporelli, K. L. (2013). Obesidad: Un desafío para las políticas públicas [Obesity: A challenge for public policy]. Estudios Sociales: Revista de Investigación Científica, 21(41), 166-184. https://bit. ly/mussini-temporelli-2013

Norton, P. A., Falciglia, G. A., \& Ricketts, C. (2000). Motivational determinants of food preferences in ado- 
lescents and pre-adolescents. Ecology of Food and Nutrition, 39(3), 169-182. https://doi.org/10.1080/ 03670244.2000 .9991613

Olivares, S., Yáñez, R., \& Díaz, N. (2003). Publicidad de alimentos y conductas alimentarias en escolares de $5^{\circ}$ a $8^{\circ}$ básico. [Food advertising and eating behaviours in school children in grades 5-8]. Revista Chilena de Nutrición, 30(1), 36-42. http://dx.doi.org/10.4067/ S0717-75182003000100005

Peña, M., \& Bacallao, J. (2005). La obesidad en la pobreza: Un problema emergente en las Américas [Obesity in poverty: An emerging problem in the Americas]. Revista Futuros, 3(10), 3-11.

Pergher, R. N. Q., Melo, M. E. D., Halpern, A., \& Mancini, M. C. (2010). O diagnóstico de síndrome metabólica é aplicável às crianças? [Is the diagnosis of metabolic syndrome applicable to children?]. Jornal de Pediatria, 86(2), 101-108. https://doi.org/10.1590/S002175572010000200004

Philipson, T., \& Posner, R. (2003). The long-run growth in obesity as a function of technological change. Perspectives in Biology and Medicine, 46(3), 87-198. https://doi.org/10.3386/w7423

Powell, L., Auld, M., Chaloupka, F., O'Malley, P., \& Johnston, L. (2006). Access to fast food and food prices: Relationship with fruit and vegetable consumption and overweight among adolescents. Advances in Health Economics and Health Service Research, 17, 23-48. https://doi.org/10.1016/S0731-2199(06) 17002-8

Procter, K. L., Clarke, G. P., Ransley, J. K., \& Cade, J. (2008). Micro-level analysis of childhood obesity, diet, physical activity, residential socioeconomic and social capital variables: Where are the obesogenic environments in Leeds? Area, 40(3), 323-340. https://doi. org/10.1111/j.1475-4762.2008.00822.x

Qutteina, Y., De Backer, C., \& Smits, T. (2019). Media food marketing and eating outcomes among pre-adolescents and adolescents: A systematic review and meta-analysis. Obesity Reviews, 20(12), 1708-1719. https://doi.org/10.1111/obr.12929

Ramos-Serrano, M., \& Herrero-Diz, P. (2016). Unboxing and brands: YouTubers phenomenon through the case study of evantubehd. Prisma Social, 1, 90-120. https://bit.ly/ramos-herrero-2016

Reis, C. E. G., Vasconcelos, I. A., \& Barros, J. F. D. N. (2011). Políticas públicas de nutrição para o controle da obesidade infantil [Public nutrition policies to control childhood obesity]. Revista Paulista de Pediatria, 29(4), 625-633. https://doi.org/10.1590/S010305822011000400024

Reis, C. E. G., Vasconcelos, I. A., \& Oliveira, O. M. (2011). Panorama do estado antropométrico dos escolares brasileiros [Overview of the anthropometric status of Brazilian schoolchildren]. Revista Paulista de Pediatria, 29(1), 108-116. https://doi.org/10.1590/S0103-

\section{7}

Robinson, T. N., Borzekowski, D. L. G., Matheson, D. N., \& Kraemer, H. C. (2007). Effects of fast-food branding on young children's taste preferences. Archives of Pediatrics \& Adolescent Medicine, 161(8), 792-797. https://doi.org/10.1001/archpedi.161.8.792

Ruvalcaba-Ledezma, J. C., Hernández-Barrera, J., GarcíaDíaz, J. R., Lozano-Jaén, A., Morales-García, L. I., Hernández-Medina, M. S., Islas-Vega, I., RiveraGómez, M. C., \& Reynoso-Vázquez, J. (2018). Factores desencadenantes de obesidad infantil, un problema de salud pública [Triggers of childhood obesity, a public health problem]. Journal of Negative and No Positive Results, 3(8), 558-673. https://doi.org/ 10.19230/jonnpr.2542

Temporelli, K., \& Monterubbianessi, P. (2011). Obesidad y sobrepeso: También una cuestión económica [Obesity and overweight: Also an economic issue]. Reunión Anual de la Asociación Argentina de Economía Política (pp. 1-19). Asociación Argentina de Economía Política. https://bit.ly/temporelli-2011

Tenorio, A., \& Cobayashi, F. (2011). Obesidade infantil na percepção dos pais [Childhood obesity in the perception of parents]. Revista Paulista de Pediatría, 29(4), 634-639. http://doi.org/10.1590/ S0103-05822011000400025

Tur-Viñes, V., González-Río, M. J. (2019). Youtubers and Community Management strategies. Revista Latina de Comunicación Social, 74, 1291-1307. https://doi. org/10.4185/RLCS-2019-1384en

Utter, J., Scragg, R., \& Schaaf, D. (2006). Associations between television viewing and consumption of commonly advertised foods among New Zealand children and young adolescents. Public Health Nutrition, 9(5), 606-612. https://doi.org/10.1079/phn2005899

Vázquez, S., Cabello, M., \& Montemayor, E. (2010). La obesidad infantil: Más que una cuestión de alimentación [Childhood obesity: More than just a question of nutrition]. In M. Cabello \& S. Garay (Eds.), Obesidad y prácticas alimentarias: Impactos a la salud desde una visión multidisciplinaria [Obesity and dietary practices: Health impacts from a multidisciplinary perspective] (pp. 81-110). Universidad Autónoma de Nuevo León.

Wiecha, J. L., Peterson, K. E., Ludwig, D. S., Kim, J., Sobol, A., \& Gorkmaker, S. L. (2006). When children eat what they watch: Impact of television viewing on dietary intake in youth. Archives of Pediatrics \& Adolescent Medicine, 160(4), 436-442. https://doi.org/ 10.1001/archpedi.160.4.436

World Health Organization. (2016). Report of the commission on ending childhood obesity (WS 130). https:// bit.ly/who-2016

YouTube (n.d.). YouTube by the numbers (as of 12 January 2020). YouTube Official Blog. https://blog.youtube/ press 


\section{About the Authors}

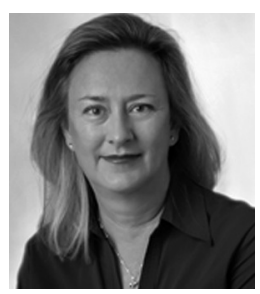

Victoria Tur-Viñes (PhD), is a professor at the Department of Social Psychology and Communication, University of Alicante. She is the author of the books Toy Advertising Communication on Television (2004), Children's Marketing (2008), and numerous scientific papers. She is also the principal investigator for the Communication and Specific Audiences Research Group, editor of Mediterranean Journal of Communication, and winner of the 14th Hermes Prize (2017) awarded by ATR-CV (ICMedia) for teaching and research in support of responsible communication. Her main lines of research are scientific communication, advertising creativity, communication, and childhood.

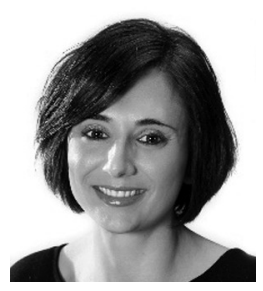

Araceli Castelló-Martínez (PhD), is a teacher at University of Alicante with a six-year term by AVAP (2009-2014) and CNEAI (2011-2017). She teaches advertising and public relations and is coordinator of the subject "innovation in the communication of creative industries" of the official MA in communication and creative industries. She has more than 1,700 citations in Google Scholar, with an h-index of 21 and an i10 index of 36 . Her main areas of research are digital communication, creative strategy, and persuasive communication aimed at different audiences, such as women or minors.

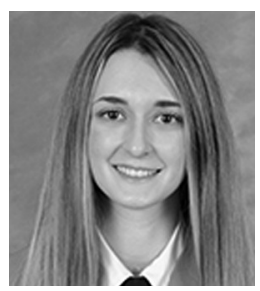

Cecilia Barrilero-Carpio is a graduate in advertising and public relations from the University of Alicante with a MA in digital marketing (Complutense University of Madrid). She specialized in social media as a social media consultant. She also co-authored two scientific papers. 